\title{
Comparative analysis of the subcutaneous musculature in some hystricomorph rodents (Rodentia: Hystricomorpha)
}

\author{
Olga V. Zherebtsova
}

\begin{abstract}
The structure of the subcutaneous musculature (m. cutaneus trunci) in three species of hystricomorph rodents (Hystricomorpha): Dasyprocta leporina (Linnaeus, 1766), Chinchilla lanigera Bennett, 1829, and Octodon degus (Molina, 1782), was studied. The members of two other suborders of Rodentia, Rattus norvegicus (Berkenhout, 1769) (suborder Myomorpha) and Spermophilus citellus (Linnaeus, 1766) (suborder Sciuromorpha), were also included in the morphological analysis for comparative purposes. In these two forms, the $\mathrm{m}$. cutaneus trunci is more simple and formed by a single muscular layer, terminating on the medial side of the humerus (medial head). This structure of the subcutaneous muscle is usually considered as more primitive, and probably close to its initial state which is characteristic of ancestral forms of Rodentia. In all hystricomorphs studied, a considerable differentiation and complication of the subcutaneous muscle is observed. In this case, a lateral head of the $\mathrm{m}$. cutaneus trunci, inserting on the lateral aspect of the forelimb, is developed. The appearance of the pars thoracoabdominalis in the structure of the subcutaneous muscle is also a specific feature of the hystricomorph rodents. At the same time, in $D$. leporina and C. lanigera, a medial head of the m. cutaneus trunci is still well expressed, but in $O$. degus, it is almost lost. It can be assumed that the progressive development and complication of the subcutaneous muscle in the evolution of hystricomorphs was largely conditioned by the requirement to improve their locomotor functions during a broad adaptive radiation of this group.
\end{abstract}

KEY WORDS: Dasyprocta, Chinchilla, Octodon, Rattus, Spermophilus, m. cutaneus trunci, subcutaneous musculature.

OlgaV. Zherebtsova [hedgol@yandex.ru], Zoological Institute of the Russian Academy of Sciences, Universitetskaya nab. 1, Saint Petersburg 199034, Russia.

\section{Сравнительный анализ подкожной мускулатуры некоторых гистрикоморфных грызунов (Rodentia: Hystricomorpha)}

\section{О.В. Жеребцова}

РЕЗЮМЕ. Проведено изучение строения подкожной мускулатуры (m. cutaneus trunci) у трех видов гистрикоморфных грызунов (Hystricomorpha): Dasyprocta leporina (Linnaeus, 1766), Chinchilla lanigera Bennett, 1829 и Octodon degus (Molina, 1782). В сравнительный морфологический анализ включены также представители двух других подотрядов Rodentia: Rattus norvegicus (Berkenhout, 1769) (подотряд Myomorpha) и Spermophilus citellus (Linnaeus, 1766) (подотряд Sciuromorpha). У этих двух форм m. cutaneus trunci - более простая и представлена однослойным мышечным пластом, оканчивающимся на медиальной стороне плечевой кости (медиальная головка). Такое строение подкожной мышцы обычно рассматривается как более примитивное и, вероятно, близкое к ее исходному состоянию, характерному для предковых форм Rodentia. У всех исследованных гистрикоморф наблюдается значительная дифференциация и усложнение подкожной мышцы. В этом случае развивается латеральная головка $\mathrm{m}$. cutaneus trunci, прикрепляющаяся на латеральной стороне передней конечности. Появление в строении подкожной мышцы pars thoracoabdominalis - также специфическая особенность гистрикоморфных грызунов. В то же время у D. leporina и C. lanigera еще хорошо выражена медиальная головка m. cutaneus trunci, а у Octodon degus она почти утрачена. Можно предположить, что прогрессивное развитие и усложнение подкожной мышцы в эволюции гистрикоморф было во многом обусловлено потребностью в совершенствовании их локомоторных функций во время широкой адаптивной радиации этой группы.

КЛЮЧЕВЫЕ СЛОВА: Dasyprocta, Chinchilla, Octodon, Rattus, Spermophilus, m. cutaneus trunci, подкожная мускулатура. 


\section{Introduction}

The subcutaneous musculature of rodents, as well as many other mammals, was still studied quite poorly. Besides general review papers on the skin musculature of mammals (Budnikow \& Wolossjuk, 1932; Jouffroy, 1971), a number of works, demonstrating the structure of the $\mathrm{m}$. cutaneus trunci, as a rule, in individual representatives of Rodentia, is known (Parsons, 1894; Langworthy, 1925; Howell, 1926; Green, 1935; Enders, 1937; Meinertz, 1941; Bryant, 1945; Rinker, 1954; Gambaryan \& Dukel'skaja, 1955; Klingener, 1964).

In this respect, the study of Woods and Howland (1977) is a first significant step towards finding features of the structure and functions of the subcutaneous muscle in a whole group of hystricomorph rodents (Hystricomorpha). Their detailed analysis of the 12 members of this suborder, differed in directions of adaptations has showed that the structure of the $\mathrm{m}$. cutaneus trunci in all these forms is characterized by surprising uniformity and complexity. However, the authors noted that many of the issues raised remain unanswered, therefore to find out the nature of the subcutaneous muscle in rodents the further comparative studies on extended range of the forms are necessary.

Hystricomorph rodents (suborder Hystricomorpha) are rather large subdivision within Rodentia, which includes a great variety of adaptation forms (Walker, 1964; Woods \& Kilpatrick, 2005). Therefore, an identification of both general and specific characteristics of their musculoskeletal system, inherent in certain families and genera, is important. Further comparative research of the specificity of the $\mathrm{m}$. cutaneus trunci in hystricomorphs could clarify the main path of its transformation in the evolution not only of rodents, but also other mammals.

This paper presents a comparative study of the subcutaneous musculature in three members of the three families of hystricomorphs: Dasyprocta leporina (Linnaeus, 1766) (Dasyproctidae), Octodon degus (Molina, 1782) (Octodontidae), and Chinchilla lanigera Bennett, 1829 (Chinchillidae). Among these forms, D. leporina was investigated for the first time. For comparison, the rodents of suborders Myomorpha (Rattus norvegicus (Berkenhout, 1769)) and Sciuromorpha (Spermophilus citellus (Linnaeus, 1766)) were also studied.

\section{Material and methods}

Three species of hystricomorph rodents (suborder Hystricomorpha) from the collections of the Zoological Institute of the Russian Academy of Sciences (Saint Petersburg, Russia) were studied: agouti Dasyprocta leporina (Dasyproctidae) $(n=2)$; long-tailed chinchilla Chinchilla lanigera (Chinchillidae) $(n=2)$; degu Octodon degus (Octodontidae) $(n=1)$. The members of the suborders Myomorpha (brown rat Rattus norvegicus; $n=2$ ) and Sciuromorpha (European ground squir- rel Spermophilus citellus; $n=1$ ) were also used as a control group.

The adult specimens were preserved in $70 \%$ ethanol or $5 \%$ formalin. The subcutaneous muscles were studied using the total preparations. For determination of the general arrangement of these muscles and the details of their relationships a specific stain for myosin (i.e., water solution of Cresil-fast-Violet) was applied. The stain was dropped on the surface of the muscles and washed away after 10-15 minutes under a strong water stream. Subsequently, the stained muscle fibres were examined with a binocular stereomicroscope Leica MZ6.

\section{Results}

Subcutaneous musculature of the brown rat Rattus norvegicus and European ground squirrel Spermophilus citellus

Since there are significant similarities in the subcutaneous muscle of these two rodents, their description is carried out in parallel, noticing the most distinguishing features.

In both species, the $\mathrm{m}$. cutaneus trunci is a singlelayer muscle, covering the whole dorsal, lateral, and ventral surface of the body (Figs 1, 5A, 6A). For convenience, it can be subdivided into a several parts, smoothly transiting into one another, but characterized by a different direction and origin of the fibers. At the same time, we accept for the origins of the individual muscular portions, those ends, which are located more proximal on the body - similarly as in the description of the limb muscles. However, in Woods and Howland (1977), a different approach in description of the $m$. cutaneus trunci based on the notion of its genetic origin (Langworthy, 1925) was applied.

M. cutaneus trunci pars dorsalis (Figs 1, 5A): its cranial fibers in both rodents, originate along the middle line of the back (from the level of the spinous process of the fourth thoracic vertebra), intertwining usually in this area with those of the antimere; further they extend almost ventrally. The following more caudal muscle fibers also arise along the dorsal midline, but run already cranial-ventrally.

M. cutaneus trunci pars caudalis (Figs 1, 5A): the next more caudal part of the muscle fibers in $R$. norvegicus originate from the superficial fascia at the base of the tail, then pass ahead parallel to the axis of the body, gradually deflecting ventrally. In $S$. citellus, a similar portion arises more cranially on the superficial fascia in the sacral region.

M. cutaneus trunci pars femoralis (Figs 1, 5A, 6A): originates on the superficial fascia of the lateral side of the thigh, extending forward with a small ventral component. In $S$. citellus, as compared with $R$. norvegicus, this portion begins on the surface of the thigh more caudally.

M. cutaneus trunci pars ventralis (Figs 1, 6A): in both rodents, originates widely along the ventral midline; further its fibers pass cranial-dorsally. 


\section{m. cutaneus trunci (medial head)}

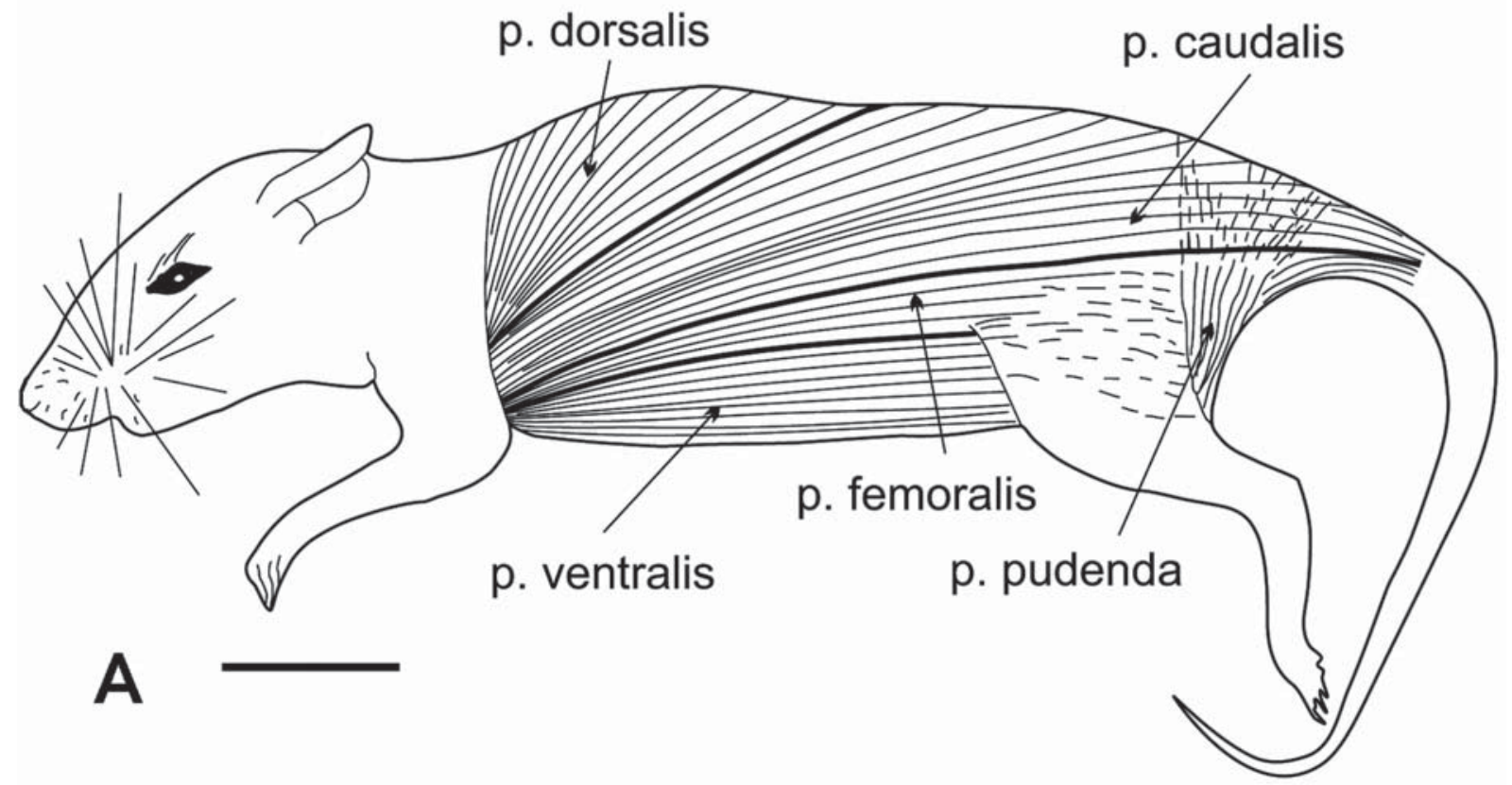

m. cutaneus trunci (medial head)

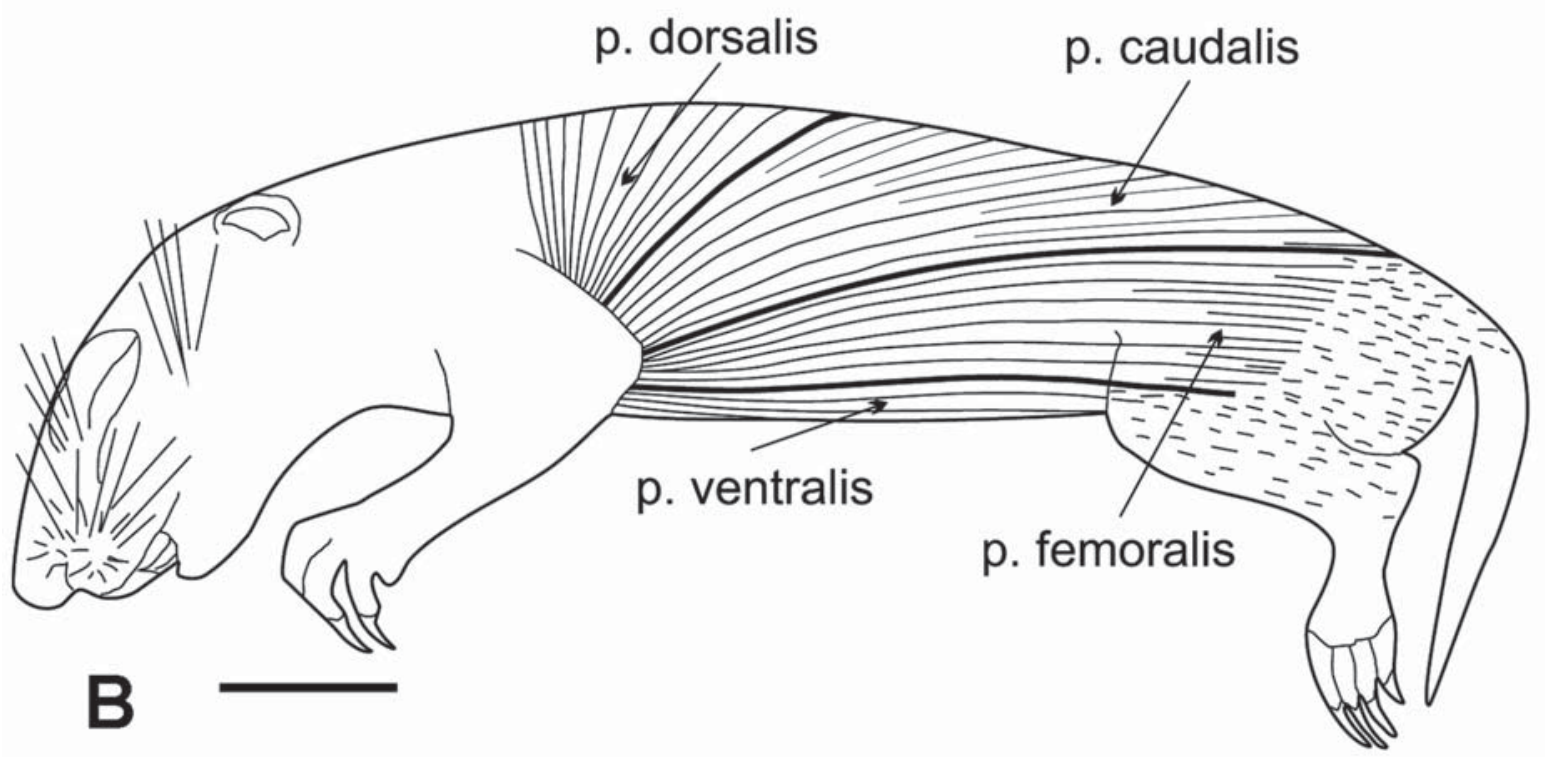

Fig. 1. The subcutaneous musculature in rodents (lateral view): A - Rattus norvegicus; B - Spermophilus citellus. Scale bars - $20 \mathrm{~mm}$. Abbreviations: m. - musculus; p. — pars.

M. cutaneus trunci pars pudenda (Fig. 1A): in $R$. norvegicus, originates by a thin aponeurosis over the $\mathrm{p}$. caudalis at the level of the sacrum. Further the muscle passes ventrally, gradually deviating in the cranial direction, and terminates on the ventral side of the body in the inguinal region. In $S$. citellus, on this area a significant part of fat is observed, and muscle fibers are not traced.

In $R$. norvegicus, all parts of the $\mathrm{m}$. cutaneus trunci mentioned above (except the p. pudenda) gradually converge to the armpit and transform into a thin apo- neurosis, which fuses together with the m. pectoralis profundus and inserts onto the humerus. The area of their common attachment is situated on the line, running along the dorsal surface of the deltoid crest of the humerus (more medial and proximal to the insertion of the m. pectoralis superficialis); then it extends on the tuberculum major and partly on the caudal part of the tuberculum minor of the humerus; moreover, the cranial part of the fibers terminate on the coracoid process of the scapula. 
m. cutaneus truncl

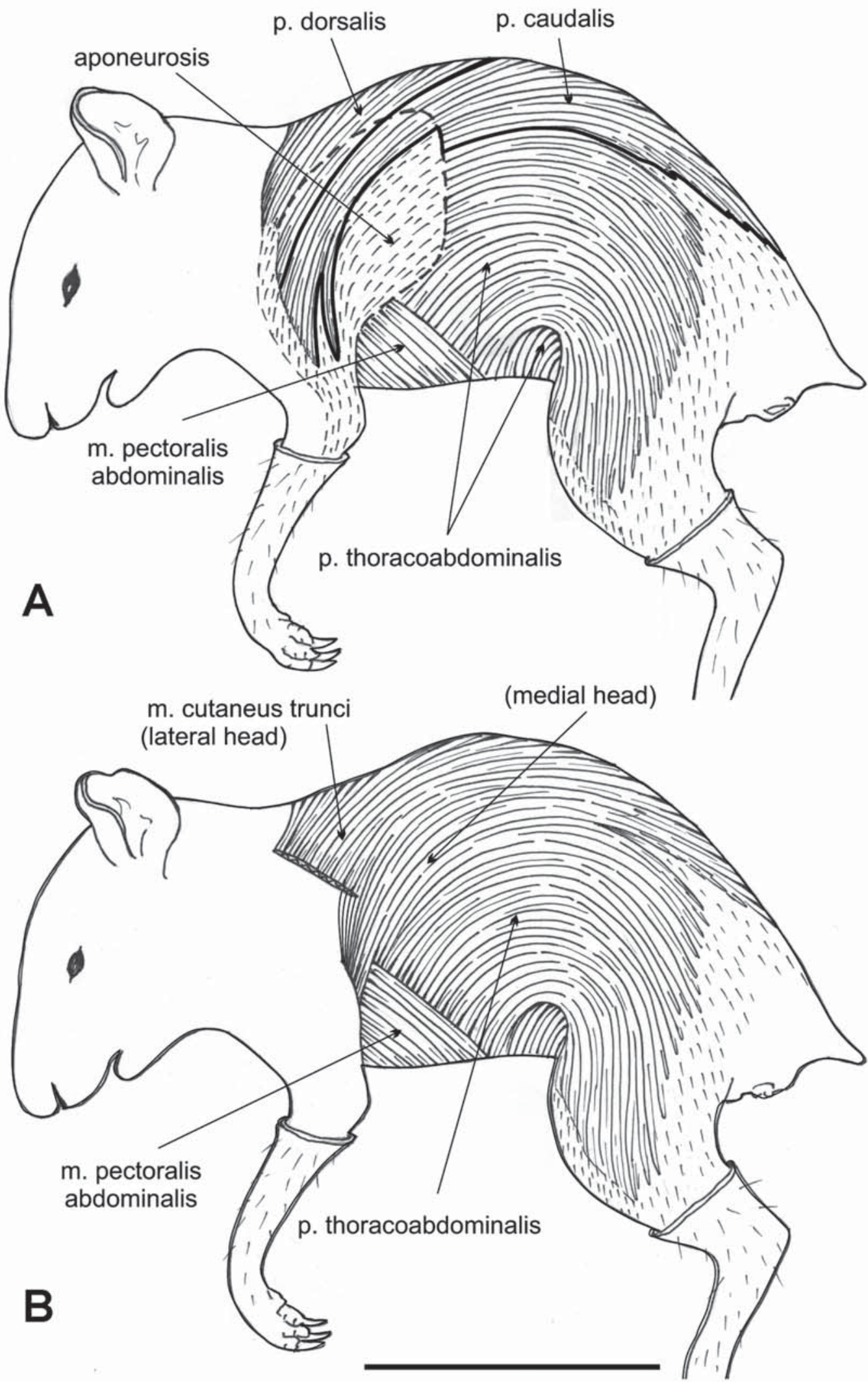

Fig. 2. The subcutaneous musculature in Dasyprocta leporina (lateral view): A - superficial layer; B - deeper regions. Scale bar - $100 \mathrm{~mm}$. Abbreviations: $\mathrm{m}$. - musculus; p. - pars; dotted line - boundary of the superficial aponeurosis. 


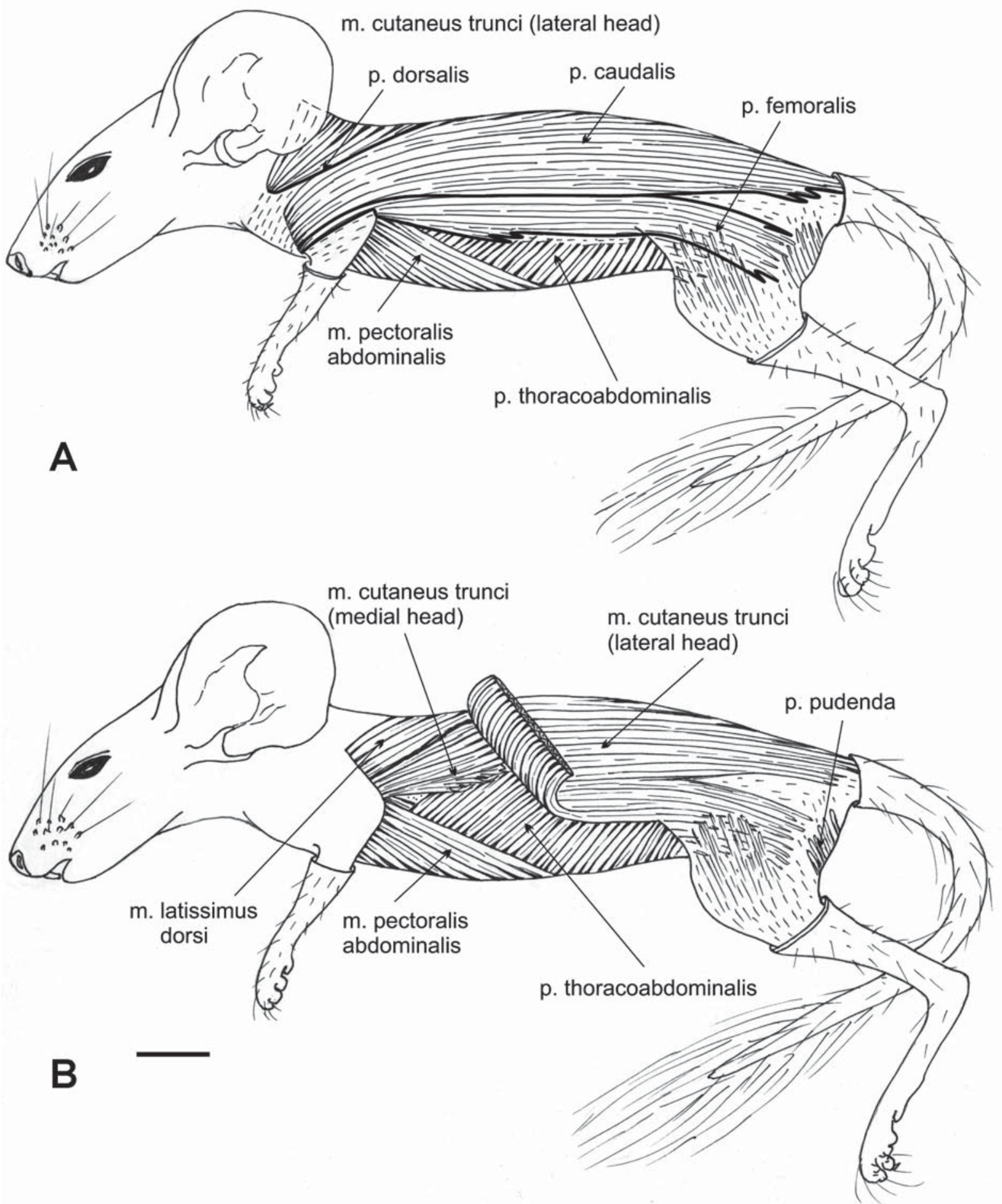

Fig. 3. The subcutaneous musculature in Chinchilla lanigera (lateral view): A — superficial layer; B — deeper layer. Scale bar - $20 \mathrm{~mm}$. Abbreviations: m. - musculus; p. — pars.

In $S$. citellus, the fibers of the subcutaneous muscle also converge to the armpit, passing from the medial side of the shoulder. Here they are partially fused by a thin aponeurosis with the $\mathrm{mm}$. pectorales profundus and abdominalis. However, in contrast to Rattus, in the vicinity of the humerus the fibers of the $\mathrm{m}$. cutaneus trunci form also a common tendon with one of the portions of the $\mathrm{m}$. latissimus dorsi. The latter is inserted onto the anterior edge of the proximal half of the deltoid crest of the humerus, passing above on the cranial area of its tuberculum major, and partly on the caudal area of the tuberculum minor. Thus, in this region, an 
integration of the three muscles: mm. cutaneus trunci, latissimus dorsi, and pectoralis, is clearly observed.

\section{The subcutaneous musculature of the hys- tricomorph rodents}

M. cutaneus trunci pars dorsalis (Figs 2-4): in all three species examined (D. leporina, C. lanigera, $O$. degus), originates, as well as the same in $R$. norvegicus and $S$. citellus, on the dorsal midline of the body (Fig. $5)$. However, in $O$. degus, a small intertwining of its fibers is observed only in the caudal part of the origin, and the cranial fibers begin by a thin aponeurosis. In $D$. leporina and $C$. lanigera, the intertwining of the fibers on the midline, on the contrary, is well expressed, so that the fibers of the opposite side even extend a little down on the side of the back. In $O$. degus, compared with other forms, the origin of the p. dorsalis is slightly shifted cranial. In all three forms studied, the cranial fibers of the $\mathrm{p}$. dorsalis go away from the midline of the back almost ventrally; more caudal fibers pass cranioventrally.

The insertion of the $\mathrm{p}$. dorsalis in hystricomorph rodents differs significantly from that of $R$. norvegicus and S. citellus, primarily to the fact that is located on the lateral surface of the forelimb. In D. leporina, there is muscle insertion on the basal fourth of the scapular spine, and by a thin aponeurosis on its metacromion process. In $C$. lanigera, muscular ending is observed only on the whole metacromion from its caudal side.

In $O$. degus, the cranial fibers of the p. dorsalis are the shortest and insert by a thin aponeurosis on the lateral surface of the neck. The next portion of more caudal fibers terminate on the metacromion process (outside - by aponeurosis, inside - muscularly). The most caudal fibers of this portion terminate similarly, but along the deltoid crest of the humerus.

M. cutaneus trunci pars caudalis (Figs 2-4): its structure and the origin in hystricomorphs have much in common with the same portion in $R$. norvegicus and $S$. citellus (Fig 5). In D. leporina, as well as in S. citellus, this portion arises from the superficial fascia in the sacral region. In $C$. lanigera and $O$. degus, its fibers begin more caudal, as well as in Rattus, but have more strong attachment: in chinchilla - on the spinous processes of the second and third caudal vertebrae, and in degus - tendinously and only on the third caudal vertebra. In both species, however, part of the ventral fibers originates on the superficial fascia near the tail base.

In all three species of hystricomorph rodents, the fibers of the $p$. caudalis extend in the cranial direction, approaching along the midline of the back and gradually more and more deviating ventrally.

The insertion of the $\mathrm{p}$. caudalis in hystricomorphs differs significantly from that described above in $R$. norvegicus and $S$. citellus, because it is located on the lateral surface of the shoulder. In D. leporina, on this area the muscle fibers gradually transform in a transparent aponeurosis, covering the surface of the $\mathrm{m}$. triceps lateralis, and partly also spreading on the forearm. Besides, in agouti, one else superficial layer, covering the muscular layer of the $\mathrm{p}$. caudalis by a dense aponeurosis, is observed here. It begins on the lateral surface of the thorax, and terminates in the shoulder region (on the Fig. 2A, this aponeurosis boundaries are indicated by a dotted line).

However, in D. leporina, in addition to a lateral head of the $\mathrm{m}$. cutaneus trunci, there is also a medial head. It is homologous to that observed in $R$. norvegicus and S. citellus, and goes as a ventral portion of the p. caudalis to the armpit from the medial side of the shoulder. In this area, it first passes over the m. pectoralis abdominalis, and the dorsal part of the latter is inserted onto inner surface of the medial head. Then, its fibers spread partly under the $\mathrm{m}$. pectoralis profundus, fusing with it. The rest of the fibers of the medial head extend over the m. pectoralis profundus, gradually forming a tendon, which fuses with its superficial fascia.

Moreover, the medial head of the $\mathrm{m}$. cutaneus trunci in agouti largely covers a ventral part of the m. latissimus dorsi. The superficial fibers of the latter transform into independent tendon, which goes to the medial side of the shoulder. At the same time, a deeper portion of the $\mathrm{m}$. latissimus dorsi penetrates under the dorsal fibers of the medial head, and gradually fuses with the $\mathrm{m}$. pectoralis profundus; then it goes with the latter to its insertion onto the deltoid crest from his medial side. Thus, in the region of armpit a fusion of the three muscles (medial head of the $\mathrm{m}$. cutaneus trunci, mm. pectorales and latissimus dorsi) is observed.

In $C$. lanigera, the $\mathrm{p}$. caudalis also is formed by two heads of the subcutaneous muscle. The fibers of the superficial lateral head insert onto the deltoid crest from its lateral side (outside - tendinously). The deeper fibers of the medial head, which firmly fused behind with the superficial lateral head, in the region of the armpit gradually transform into a tendon. It merges with the superficial fascia of the $\mathrm{m}$. pectoralis abdominalis which goes on the medial side of the humerus and inserts onto its deltoid crest. The regions of the insertion of the pectoral muscles in $C$. lanigera have been described and indicated in detail in earlier work of Gambaryan et al. (2013). Dorsal fibers of the medial head cover a ventral part of the m. latissimus dorsi, but in this case, there is no connection between these muscles. The ventral margin of the medial head fuses with deeper lying $\mathrm{p}$. thoracoabdominalis (see below).

In O. degus, the p. caudalis is formed by only superficial fibers of the lateral head which are inserted by a thin aponeurosis on the continuation of the deltoid crest of the humerus from its lateral side. This aponeurosis connects with a superficial fascia of the forearm.

M. cutaneus trunci pars femoralis (Figs 3-4): among three species studied, is observed in $C$. lanigera and $O$. degus, and in the latter it is less expressed in its origin on the superficial lateral fascia of the thigh. From this region, its muscle fibers spread cranially, however, do not continue in the region of the axilla, as in the case of 


\section{m. cutaneus trunci (lateral head)}

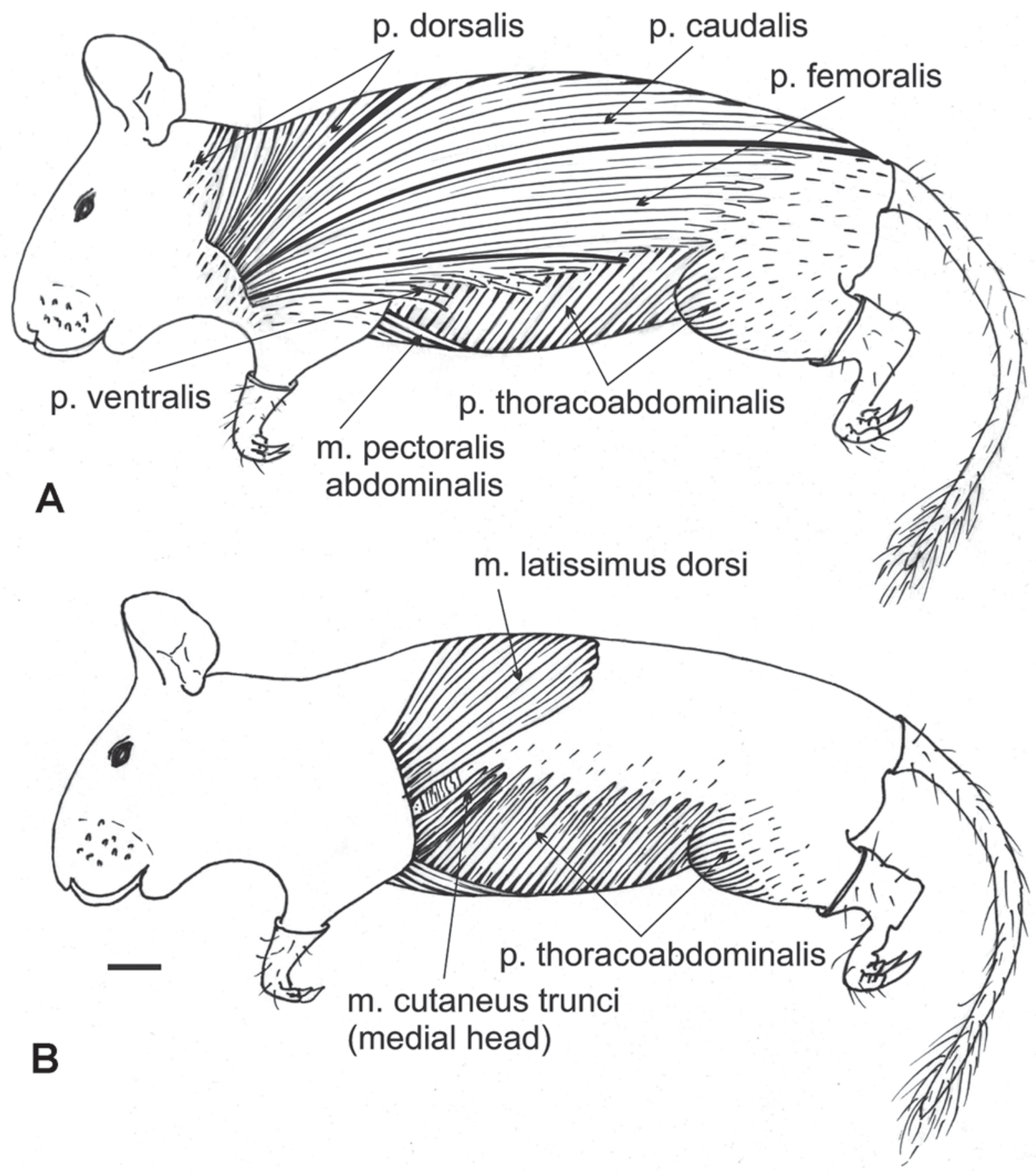

Fig. 4. The subcutaneous musculature in Octodon degus (lateral view): A — superficial layer; B — deeper layer. Scale bar $10 \mathrm{~mm}$. Abbreviations: m. - musculus; p. — pars.

$R$. norvegicus and $S$. citellus, but terminate on the lateral surface of the shoulder: in $O$. degus, along line of the deltoid crest continuation up to the distal part of the humerus (outside - by aponeurosis, inside - muscularly), then passing into fascia of the forearm; in $C$. lanigera, similar, but mainly fascial. It can be noted that on the same line of the deltoid crest continuation, the $\mathrm{mm}$. pectorales are inserted, but from the medial side.

D. leporina also has a muscular portion that begins on the lateral surface of the thigh by a very dense aponeurosis, but mainly inserts quite different: on the ventral middle line of the thorax and abdomen, so that was called the pars thoracoabdominalis (see below). 

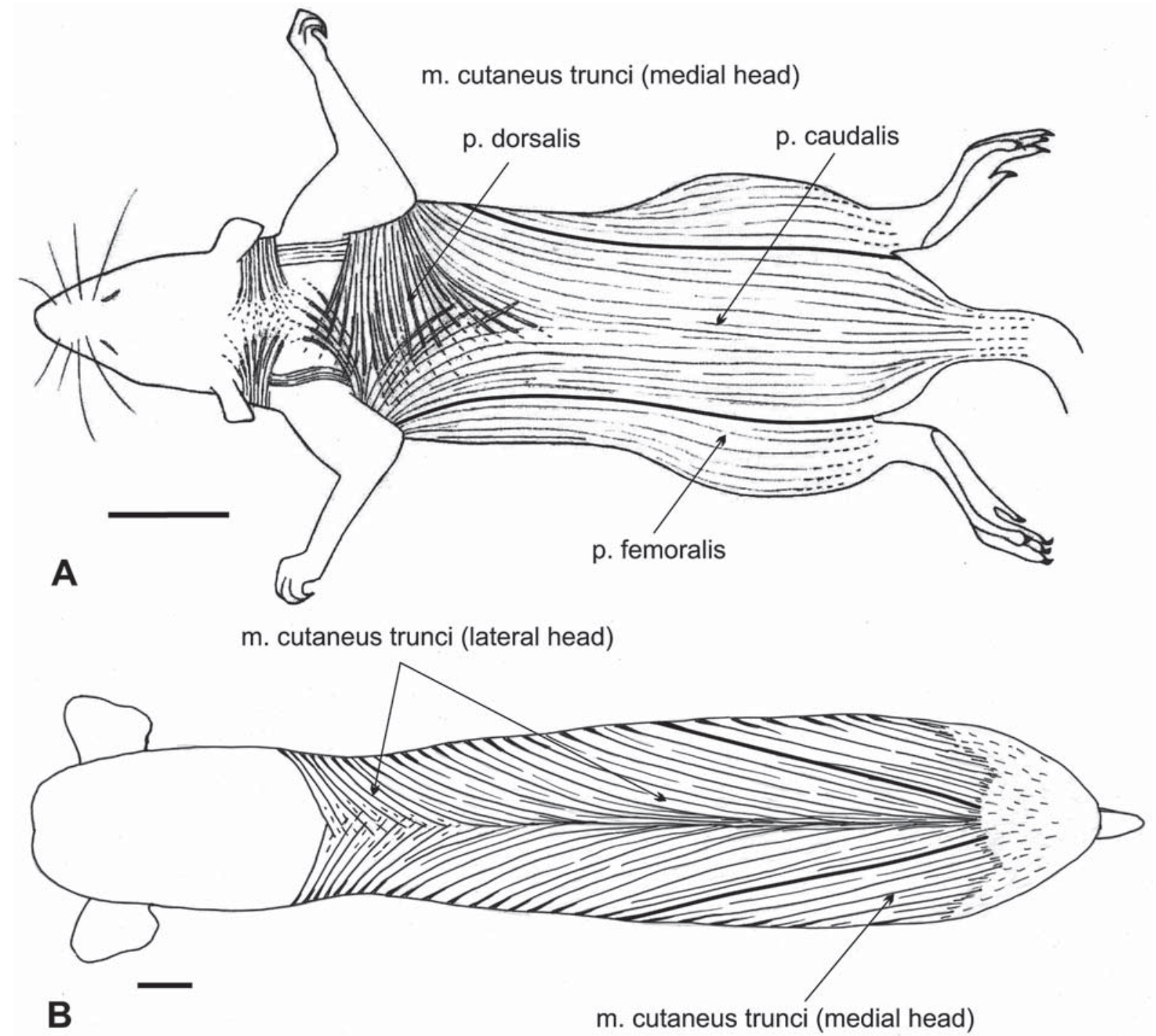

Fig. 5. The subcutaneous musculature in rodents (dorsal view): A — Rattus norvegicus; B — Dasyprocta leporina. Scale bars $20 \mathrm{~mm}$. Abbreviations: m. - musculus; p. — pars.

However, its most dorsal fibers, originating in the thigh region, merge into a single layer with the ventral fibers of the p. caudalis. Together with them, they are partially included in the medial head of the m. cutaneus trunci, fusing with the pectoral muscles in the armpit (see above).

M. cutaneus trunci pars thoracoabdominalis (Figs 2-4, 6B): in D. leporina, as mentioned above, forms a single layer with the other portions of the $\mathrm{m}$. cutaneus trunci. Its fibers spread cranial from a dense aponeurosis in the thigh region, gradually deviating more and more in the ventral direction. Approaching to the shoulder region, they penetrate under the $\mathrm{mm}$. pectorales abdominalis and profundus, and are inserted onto the ventral midline from the level of the III-IVth ribs and up to the inguinal region. In this case, a cranial portion of the fibers does not reach the midline, terminating on the inner fascia of the $\mathrm{m}$. pectoralis profundus. The fibers, inserting most caudal, originate most ventral in the femoral region.

In $C$. lanigera, the $\mathrm{p}$. thoracoabdominalis, unlike that of $D$. leporina, does not form a single layer with more dorsal parts of the $\mathrm{m}$. cutaneus trunci. Its fibers begin on the internal surface of the $p$. femoralis and $p$. caudalis of the lateral head of subcutaneous muscle, and pass more ventrally in relation to them. Then they penetrate under the pectoral muscles and terminate on the ventral midline of the body, caudally from the level of the third rib. The cranial portion of the fibers fuses with the medial head of the $\mathrm{m}$. cutaneus trunci on the lateral side of the body.

In $O$. degus, in contrast to the two previous species, the $\mathrm{p}$. thoracoabdominalis forms a separate layer of fibers, originating mainly in the inner fascia of the 


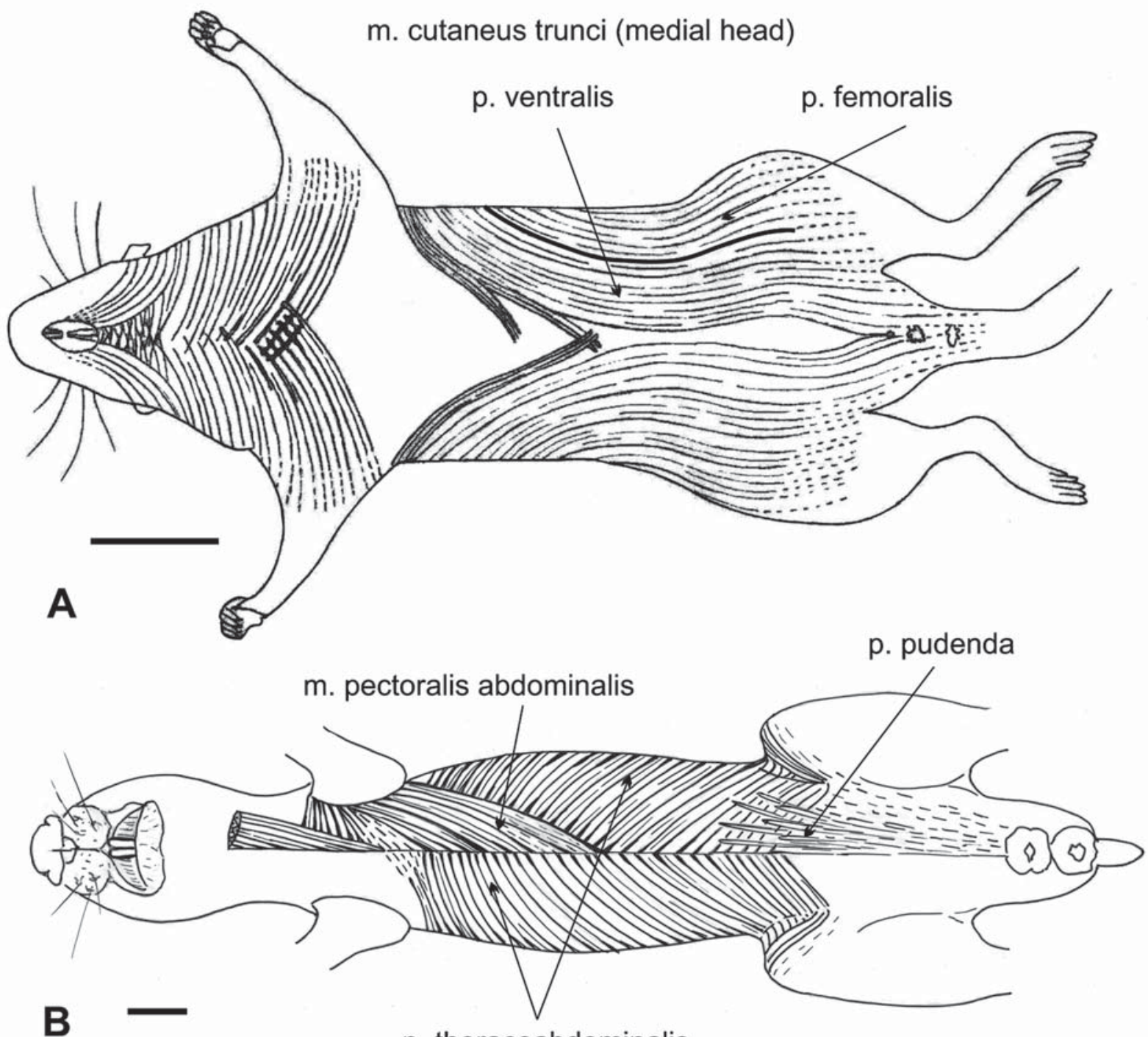

p. thoracoabdominalis

Fig. 6. The subcutaneous musculature in rodents (ventral view): A - Rattus norvegicus; B - Dasyprocta leporina. Scale bars - $20 \mathrm{~mm}$. Abbreviations: m. - musculus; p. - pars.

lateral head of subcutaneous muscle and extending the cranio-ventrally. Then it passes under the mm. pectorales abdominalis and profundus, on the internal fascia of which a part of its cranial fibers terminate. The remainder goes to the abdominal midline and inserts there, posteriorly from the level of the III-IVth ribs. The most caudal fibers originate on the superficial fascia of the anterior edge of the lateral surface of the thigh and, extending cranio-ventrally, pass in the inguinal region, inserting onto the ventral midline near the genitals.

It should be noted that in $O$. degus, there is a small cranial portion of fibers of the $p$. thoracoabdominalis which, in contrast to the subsequent portions, does not penetrate under the pectoral muscles, but passes over them, gradually merging with them, and extending on the medial side of the shoulder. This portion forms also a specific communication through the short transverse fibers with the $\mathrm{m}$. latissimus dorsi located here more dorsally.

M. cutaneus trunci pars ventralis (Fig. 4A): none of the three considered forms of hystricomorphs, is practically not expressed. Only in $O$. degus and $C$. lanigera, there are small fan shaped bundles of the ventral fibers, separating from the general layer of the lateral head of the $m$. cutaneus trunci and terminating on the superficial fascia of the p. thoracoabdominalis. These muscular bundles have some resemblance to the $\mathrm{p}$. ventralis in their direction.

M. cutaneus trunci pars pudenda (Figs 3B, 6B): in $D$. leporina and $O$. degus, its weak fibers are found, which origin by a thin aponeurosis in the genital region and pass a little forward on the abdominal side to their insertion on the superficial fascia of caudal part of the p. thoracoabdominalis. 
In $C$. lanigera, this portion originates by a thin aponeurosis approximately the same way, as that in $R$. norvegicus, but not over the fibers of the p. caudalis, and on the caudal part of the femoral region. Further it extends ventrally, gradually deviating in the cranial direction; then passes nearly the genitals and terminates on the ventral side of the body in the inguinal region, near the posterior edge of the $\mathrm{p}$. thoracoabdominalis.

\section{Discussion}

The comparative analysis indicated that in the representatives of the control group used, $R$. norvegicus and $S$. citellus, the structure of the subcutaneous musculature is more simple since consists only of a single layer of the medial head of the $m$. cutaneus trunci (Figs $1,7 \mathrm{~A}, \mathrm{~B})$. In this case, it covers entirely the dorsal, lateral, and ventral surfaces of the body, gradually converging to the axilla and terminating on the medial side of the humerus near the attachment of the $\mathrm{m}$. pectoralis abdominalis. It is just with this pectoral muscle the origin of the $\mathrm{m}$. cutaneus trunci is associated, the latter being innervated by the anterior thoracic nerves (Langworthy, 1925). It is believed that this structure of the subcutaneous muscle is more primitive, and probably close to its initial state, which is characteristic of the ancestral forms of Rodentia (Woods, 1972; Woods \& Howland, 1977).

A similar structure of the $\mathrm{m}$. cutaneus trunci is known in many weakly specialized forms of the myomorph and sciuromorph rodents, some marsupials, insectivorous, and carnivorous mammals (Dobson, 1882; Langworthy, 1925; Enders, 1937; Bryant, 1945, Rinker, 1954; Gambaryan \& Dukel'skaja, 1955; Klingener, 1964; Nozdrachev, 1973; Gambaryan \& Zherebtsova, 1988). In the structure of the subcutaneous muscle in relic rodent Laonastes aenigmamus Jenkins et al., 2005, the development of only medial head is also observed, that confirms once again its proximity to the ancestral state of hystricomorphs (Zherebtsova \& Davydova, 2011).

According to Woods and Howland (1977), in all hystricomorph rodents, a complex structure of the subcutaneous musculature is noticed, and our investigations of D. leporina, C. lanigera, and $O$. degus support these data. Really, compared with a control group of our research, in the three forms of hystricomorphs studied, the significant differentiation of the $\mathrm{m}$. cutaneus trunci along with the development of both the medial and lateral heads, and such characteristic portion, as pars thoracoabdominalis, are observed.

If we assume that a deep differentiation of the $m$. cutaneus trunci and more considerable development of its lateral head, in contrast to medial one, correspond to its more advanced state, that the three species of hystricomorphs examined can be arranged in the following order: D. leporina, C. lanigera, and O. degus.

Thus, in D. leporina, the $\mathrm{m}$. cutaneus trunci is almost a single-layer muscle, in which it is still difficult to distinguish the transition between the fibers of the $p$. caudalis of the lateral head and those of the medial one, and then also the fibers of the $\mathrm{p}$. thoracoabdominalis (Figs 2, 5B, 6B, 7C1, 7C2). At the same time, on the lateral side of the thorax, there is a more superficial layer of aponeurosis, covering partly the fibers of the lateral head (Fig. 2A). It should be noted a significant similarity in the structure of the subcutaneous muscle in D. leporina and another species of this genera Dasyprocta punctata Gray, 1842, described in Woods and Howland (1977).

In $C$. lanigera, on the side of the body, the separation of the subcutaneous muscle into three parts is observed: the superficial layer of the lateral head, the deeper layer of the medial head, and the p. thoracoabdominalis (Figs 3, 7D1, 7D2). Moreover, all the three parts are closely related, but the medial head is much weaker developed than the lateral one.

In $O$. degus, the lateral head of the $\mathrm{m}$. cutaneus trunci already largely dominates over the medial one, the fibers of which are scarcely visible among the cranial fibers of the p. thoracoabdominalis (Figs 4, 7E1, 7E2). In Woods and Howland (1977), the medial head was not described in $O$. degus. However, if we take into account the passage of the cranial superficial fibers of the $\mathrm{p}$. thoracoabdominalis over the $\mathrm{m}$. pectoralis abdominalis and then their fusion, and further their common insertion onto the medial side of the humerus, it will look like on a typical arrangement of the medial head of the $\mathrm{m}$. cutaneus trunci. Nevertheless, the latter is close related with the $\mathrm{p}$. thoracoabdominalis in its origin. In degu, the p. thoracoabdominalis is already significantly differentiated from the superficial fibers of the lateral head, passing almost perpendicular to them on the sides of the body.

In conclusion, it should be noted that the progressive complication of the subcutaneous musculature in mammals is usually associated with the development of any specific specializations: passive or active defense, digging activity, capacity to planning (Michelsson, 1922; Gambaryan, 1960; Johnson-Murray, 1987; Gambaryan \& Zherebtsova, 1988; Zherebtsova, 2000; Gambaryan et al., 2010). In many of these animals, along with the development of the medial, and the lateral head of the $\mathrm{m}$. cutaneus trunci are observed, the latter being significant enhanced and dominated. At the same time, there are a new data on the development of a lateral shoulder portion of the $\mathrm{m}$. cutaneus trunci in small mustelids which are characterized by specific locomotor adaptations (Davydova \& Zherebtsova, 2015). The features of the structure and attachments of this portion demonstrate a possibility of its participation in locomotor acts of these small predators.

Based on all mentioned above, it may be suggested that the progressive complication of the subcutaneous muscle in hystricomorph rodents largely connects with a requirement to improve their locomotor functions in conditions of a broad adaptive radiation of this group and its adaptation to a variety of ecological niches. It is 

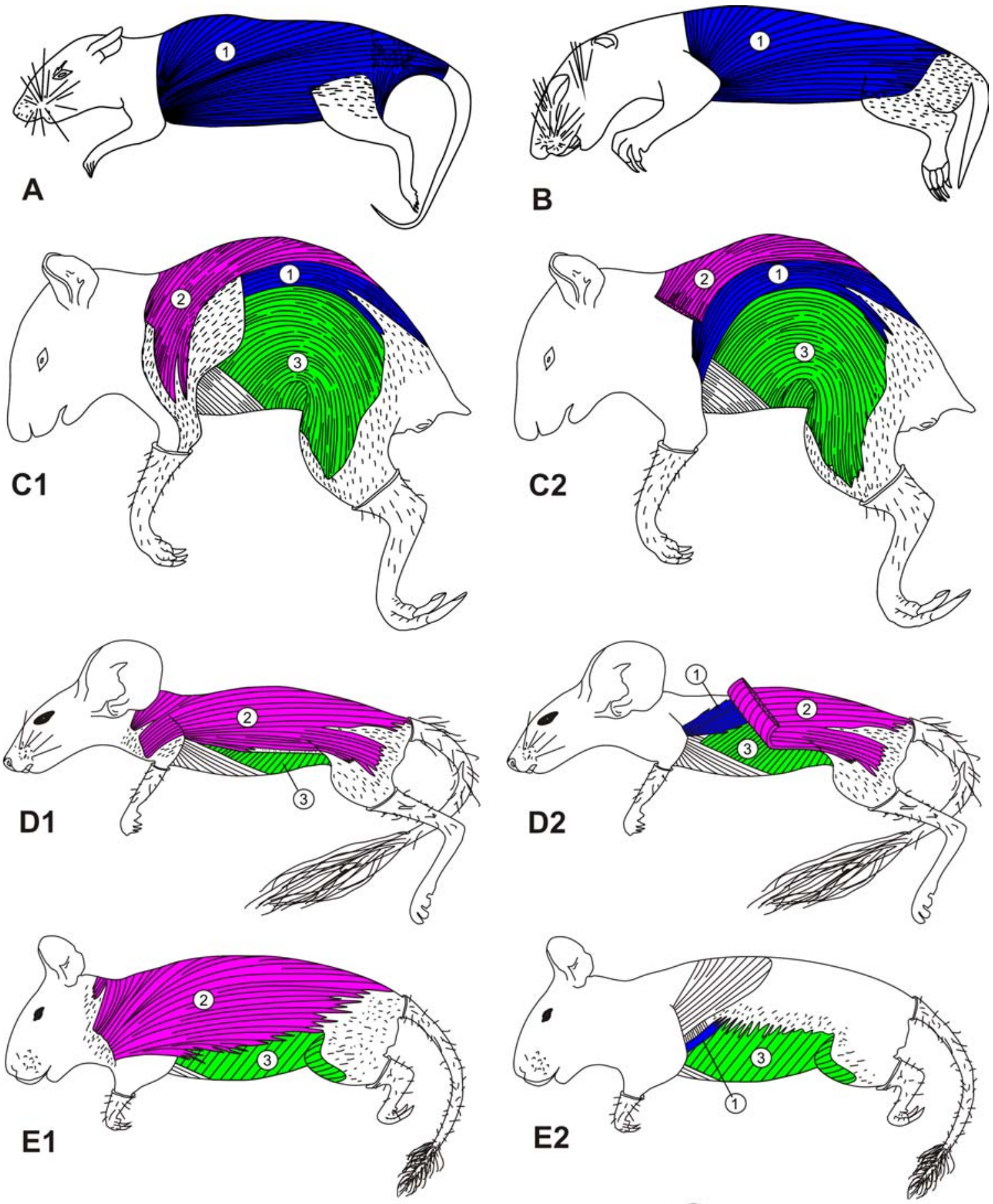

medial and

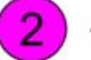

- lateral heads of the $\mathrm{m}$. cutaneus trunci

3. - pars thoracoabdominalis

Fig.7. The ratio of the different parts of the subcutaneous muscle in rodents (lateral view): A — Rattus norvegicus; B Spermophilus citellus; C1, C2 — Dasyprocta leporina; D1, D2 - Chinchilla lanigera; E1, E2 - Octodon degus; where 1 superficial layer, 2 - deeper layer.

known that the agouti, for example, can run sufficiently fast, while the degu and chinchilla are well adapted for movement in rock landscapes (Walker, 1964). Our research of jump locomotion of these animals in the experimental conditions confirms their locomotor abil- ities (Zherebtsova et al., 2016). However, it is obviously that to get answers to many of the questions, regarding the morphogenesis of the subcutaneous muscle, the comparative morpho-functional studies should be continued. 
ACKNOWLEDGEMENTS. I am grateful very much to Vladimir V. Platonov (Zoological Institute of RAS) for the substantial aid in the preparation of illustrative material. I thank also the reviewers, Dr. Vladimir G. Malikov and Dr. Alexei V. Abramov, whose valuable suggestions helped me to improve the text. The study was supported by the Russian Foundation for Basic Research (grant No. 15-04-03688).

\section{References}

Briant M.D. 1945. Phylogeny of Nearctic Sciuridae // American Midland Naturalist. Vol.33. P.257-390.

Budnikow P. \& Wolossjuk W. 1932. Zur Morphologie des M. cutaneous trunci // Anatomischer Anzeiger. Bd.73. S.204-209.

Davydova A.N. \& Zherebtsova O.V. 2015. [The subcutaneous muscles of small mustelids (Carnivora, Mustelidae)] // Proceedings of the Zoological Institute RAS. Vol.319. No.3. P.363-377 [in Russian, with English summary].

Dobson G.E. 1882. A Monograph of the Insectivora, Systematic and Anatomical. Pt.I. London: John van Voorst. $172 \mathrm{p}$.

Enders R.K. 1937. Panniculus carnosus and formation of the pouch in didelphids // Journal of Morphology. Vol.61. P.1-61.

Gambaryan P.P. 1960. [Adaptive features of the locomotor organs in fossorial mammals]. Erevan: Izdatel'stvo AN Armyanskoi SSR. 195 p. [in Russian].

Gambaryan P.P. \& Dukel'skaja N.M. 1955. [The Rat]. Moscow: Izdatel'stvo Sovetskaya Nauka. 256 p. [in Russian].

Gambaryan P.P. \& Zherebtsova O.V. 1988. [Transformation of hypodermic muscles caused by the development of acicular integument in Insectivora (Erinaceidae and Tenrecidae). Comunication 1] // Zoologicheskii Zhurnal. Vol.67. No.1. P.79-89 [in Russian, with English summary].

Gambaryan P.P., Zherebtsova O.V. \& Perepelova A.A. 2013. Comparative analysis of forelimb musculature in Laonastes aenigmamus (Rodentia: Diatomyidae) // Proceedings of the Zoological Institute RAS. Vol.317. No.3. P.226-245

Gambaryan P.P., Zherebtsova O.V. \& Platonov V.V. 2010. [Convergent development of the subcutaneous muscles in moles and golden moles] // Zhurnal Obshchei Biologii. Vol.71. No.3. P.163-175 [in Russian with English summary].

Green E.C. 1935. Anatomy of the rat // Transactions of the American Philosophical Society, N.S. Vol.27. P.1-370.

Howell A.B. 1926. Anatomy of the Wood Rat. Baltimore: the Williams and Wilkins. $230 \mathrm{p}$.

Johnson-Murray J.L. 1987. The comparative myology of the gliding membranes of Acrobates, Petauroides and Petaurus contrasted with the cutaneous myology of Hemibelideus and Pseudocheirus (Marsupialia, Phalangeridae) and with selected gliding Rodentia (Sciuridae and Anamoluridae // Australian Journal of Zoology. Vol.35. No.2. P.101-113.
Jouffroy F.K. 1971. Les peauciers du tronc et des membres et leurs derives // Traité de Zoologie. Anatomie, Systématique, Biologie. Vol.16. No.3. P.626-678.

Klingener D. 1964. The comparative myology of four dipodoid rodents (genera Zapus, Napaeozapus, Sicista, and Jaculus) // Miscellaneous Publications of Museum Zoology of the University of Michigan. No.124. P.1100.

Langworthy O.R. 1925. A morphological study of the panniculus carnosus and its genetical relationship to the pectoral musculature in rodents // American Journal of Anatomy. Vol.35. P.283-302.

Meinertz T. 1941. The skin musculature of the Greenland lemming Dicrostonyx groenlandicus (Traill.) // Meddelelser om Grønland. Vol.131. P.1-77.

Michelsson G. 1922. Die Hautmuskulatur des Igels (Erinaceus europaeus) // Morphologischer Jahrbücher. Bd.69. S.110-220.

Nozdrachev A.D. 1973. [Anatomy of Cat]. Leningrad: Izdatel'stvo Nauka. 247 p. [in Russian].

Parsons F.G. 1894. On the myology of the sciuromorphine and hystricomorphine rodents // Proceedings of the Zoological Society of London. Vol.1894. P.251-296.

Rinker G.C. 1954. The comparative myology of the mammalian genera Sigmodon, Oryzomys, Neotoma, and Peromyscus (Cricetinae), with remarks of their intergeneric relationships // Miscellaneous Publications of Museum Zoology of the University of Michigan. No.83. P.1-124.

Walker E.P. 1964. Mammals of the World. Baltimore: John Hopkins Press. Vol.2. 320 p.

Woods C.A. 1972. Comparative myology of jaw, hyoid and pectoral appendicular regions of New and Old World hystricomorph rodents // Bulletin of the American Museum of Natural History. Vol.147. P.115-198.

Woods C.A. \& Howland E.B. 1977. The skin musculature of hystricognath and other selected rodents // Zentralblatt für Veterinarmedizin, Reihe C - Journal of Veterinary Medicine, Series C - Anatomia Histologia Embryologia. Vol.6. P.240-264.

Woods C.A. \& Kilpatrick C.W. 2005. Suborder Hystricomorpha. Infraorder Hystricognathi // Wilson D.E. \& Reeder A.M. (eds.). Mammal Species of the World. Baltimore: Johns Hopkins University Press. Vol.2. P.15381600.

Zherebtsova O.V. 2000. Spiny cover and defence strategy of mammals // Proceedings of Zoological Institute RAS. Vol.286. P.169-174.

Zherebtsova O.V. \& Davydova A.N. 2011. [Features of structure of the skin and subcutaneous muscles in Laonastes aenigmamus] // Rozhnov V.V. et al. (eds.). Proceedings of International Conference "Mammals of Russia and Adjacent Territories". IX Congress of Theriological Society, RAS. Moscow: KMK Scientific Press. P.162 [in Russian with English summary].

Zherebtsova O.V., Panyutina A.A., Gambaryan P.P. \& Platonov V.V. 2016. [About jump locomotion of some rock hystricomorphs] // Theriofauna of Russia and adjacent territories. International Conference. X Congress of the Russian Theriological Society RAS. Moscow 1-5, 2016. Moscow: KMK Scientific Press. P.162 [in Russian]. 